\begin{tabular}{|c|c|}
\hline in & $\begin{array}{l}\text { International Journal of Trend in Scientific } \\
\text { Research and Development (IJTSRD) }\end{array}$ \\
\hline 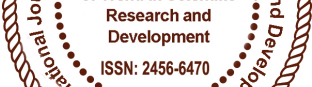 & International Open Access Journal \\
\hline 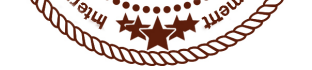 & ISSN No: 2456 - 6470 | www.ijtsrd.com | Volume - 2 | Issue - 5 \\
\hline
\end{tabular}

\title{
Improvement of Regional System of Settlement of Samarkand Region
}

\author{
M. A. Kadirov ${ }^{1}$, O. I. Sherkholov ${ }^{2}$ \\ ${ }^{1}$ Associate Professor, ${ }^{2}$ Independent Researcher \\ Samarkand State University, Samarkand (Uzbekistan)
}

\begin{abstract}
The article deals with the peculiarities of the demographic situation in the region, studies the population dynamics, average annual growth rates, population density, natural and mechanical movement of the population, labor resources, the Samarkand agglomeration and the Kattakurgan group settlement form, as well as scientific and practical conclusions are provided.
\end{abstract}

KEYWORD: Settlement system, demographic, situation, average annual growth rate, natural movement, labor resources, agglomeration, group settlement form

\section{INTRODUCTION}

The peculiarities of demographic situation in Samarkand region are first of all based on high rates of population growth, significantly exceeding those of other regions of the Republic of Uzbekistan. It is characteristic to note that intensive population growth occurs mainly due to its large natural growth. And the role of this source of demographic growth at all stages was great and it also determines the regional features of population dynamics. High and fairly stable birth rates and relatively low death rates are the main reasons for rapid growth of the population of Samarkand region.

\section{MAIN PART}

The study shows that the rates of population growth, including urban and rural areas in separate years were not the same. For example, the highest growth rates of the entire population are recorded during the years 1979-1994, and the most minimal during the years of 1939-1959.
Table 1: Average annual rate of population growth in Samarkand region (in \%)

\begin{tabular}{|c|c|c|c|}
\hline Years & $\begin{array}{c}\text { Whole } \\
\text { population }\end{array}$ & $\begin{array}{c}\text { Urban } \\
\text { population }\end{array}$ & $\begin{array}{c}\text { Rural } \\
\text { population }\end{array}$ \\
\hline $\begin{array}{c}1926- \\
1939\end{array}$ & 1,45 & 1,65 & 1,45 \\
\hline $\begin{array}{c}1936- \\
1959\end{array}$ & 0,70 & 2,80 & 0,04 \\
\hline $\begin{array}{c}1959- \\
1970\end{array}$ & 1,55 & 0,03 & 2,85 \\
\hline $\begin{array}{c}1970- \\
1979\end{array}$ & 2,60 & 8,65 & 0,45 \\
\hline $\begin{array}{c}1979- \\
1994\end{array}$ & 3,05 & 2,00 & 3,50 \\
\hline $\begin{array}{c}1995- \\
2015\end{array}$ & 2,45 & 2,45 & 2,45 \\
\hline
\end{tabular}

The maximum growth rates of urban population are found during the years of 1970-1979, which is due in turn to the high rates of gardening and industrialization of the region. In rural areas, the population increased most dynamically during the years of 1979-1994 (3.50) and relatively slowly during the years of 1939-1959 (0.04). It should be noted that the demographic development of rural areas has a more "calm" and stable character than urban areas, which is obviously connected with stable indicators of natural growth and a weak outflow of population to cities.

3.8 million people live in the Samarkand region according to the data of the year of 2018, of which about $52 \%$ live in urban areas. It is known that population density is an important indicator of settlement. It simultaneously indicates the level of economic development of the territory and its population. The total density of the region's population as a whole is 213.7 people for $1 \mathrm{~km}^{2}$ with 
the population density of Samarkand city of more than 4,4 thousand people (2016).

The natural increase in the population of the region on average for the years of 1979-1994 is about 30\%, in the year of 1994 it was equal to $29 \%$, and in 2015 it was evaluated as $20.3 \%$. At the same time the highest indicators of natural movement persist in the Payarik, Urgut, and Akdarya districts and the low rates of natural growth keep in Guzalkent and Narpay districts.

In Samarkand region rapid population growth is associated with high rates of natural movement, and not with migration growth. Analyzes indicate that in general for the years of 1979-2015 migration outflow surpasses the influx of people. The effectiveness of migration or its balance in almost all the years was negative. Consequently, the role of migration in the increment of the population of the region is increasingly becoming negative.

The formation of a contingent of labor resources in urban and rural areas has its own characteristics. According to the data of 2015 the total number of the able-bodied population in the region was more than $57 \%$. In the territory of the Samarkand region the formation of Samarkand agglomeration in its modern sense began in 1973, and in 1980 the borders of the agglomeration expanded due to the appearance of urban settlements of Jambay, Dahbed, Charkhin and Taylak. In the following year the expansion of the borders of the agglomeration was connected with the formations of the urban settlements of Farhad, Layish, and Chelak. As a result of all this Samarkand agglomeration acquired an even more complex spatial structure. Such industries as light, food, machine building and metalworking, building materials industry, etc. are mainly developed areas in the agglomeration. In addition there are large objects of social and domestic infrastructure.

In Samarkand there are research and design institutions, a wide network of health and trade facilities. Besides, there are 5 higher and 15 secondary specialized educational institutions.

In the territory of the Samarkand region one can also single out the Kattakurgan group form of settlement. It is located in the north-west of the region and includes mainly populated areas located in the leftbank part of the river Zarafshan. This system is considered within the boundaries of the Kattakurgan City Council and the three nearest rural districts Kattakurgan, Narpay, Ishtikhan, with a radius of 30$35 \mathrm{~km}$. The urban population is represented by the inhabitants of Kattakurgan, Aktash and Ishtikhan, as well as 3 urban settlements - Mirbazar, Ingichka and Mitan.

In the local group the most developed industries are food, light, construction and mining. Machinery, food and light industry are developed in Kattakurgan. In Ingichka - mining industry and etc.

\section{CONCLUSION}

Thus, the scientific and practical conclusions and proposals arising from the content of this work can be summarized as follows.

1. Improvement of the territorial organization of the population of the region assumes first of all the further strengthening of the citiy of Samarkand as the organizing center of the regional settlement system. We must understand that with the formation of the world community Tashkent city, as the capital of a sovereign state, the main tasks of a national nature can increasingly be fulfilled by regional and regional centers - like Samarkand, Fergana, Nukus and other large cities. They should ensure the territorial-economic and political-geographical integrity of the country.

2. It is known that any system, as an organized object and control, must have its own internal structure-subsystem and a system of centers of different hierarchical order. Proceeding from this, the constituent structural elements of the Samarkand regional settlement system should have its own sphere of influence. In this regard, more active development of other cities will also be required as organizing centers for pink settlement systems.

3. The study showed that the second largest city of the region-Kattakurgan is somewhat behind in its development. With the advent of the rapidly growing industrial and regional center of Navoi, the more ancient Kattakurgan lost its mediatory significance between Samarkand and Bukhara, in the region of the settlement system of the Zarafshan Valley. Now the sphere of its influence is limited only by the western regions of the Samarkand region and the adjacent part of the Navoi region.

4. Improvement of the territorial organization of the region's population is inextricably linked with the 
tasks of comprehensive development of other significant cities, such as Urgut, Bulungur, Ishtikhan, Juma and Aktash. The development of these cities should be considered in two qualitatively dissimilar systems - within the framework of integral group forms of settlement. Samarkand and Kattakurgan as part of the lower regional systems, where they themselves act as the main backbone center.

5. In solving social problems, and improving the life of the rural population, the importance of district centers is of great importance. Currently the government of the Republic of Uzbekistan provides for a significant expansion of the rights of the regional authorities of governorships to organize social and economic life on the ground. Therefore the rural district centers here must take over the responsibility for the all-round servicing of the economy of the population and its social needs. For this, it is necessary to strengthen the organizing and servicing functions of district centers, and above all, such as Koshrabad, Nurabad, Guzalkent and others. In its order additional local centers, village centers, farm system of settlement, farm centers, brigade departments.

6. In the context of deepening economic reforms of privatization, city halls of regions and regions will regulate the location of trade enterprises and other service industries, taking into account specific settlements, population density and settlements. In the solution of this urgent task, the inventory and interconnected development of the industrial and social infrastructure of all populated areas located on the territory of the rural population contributes to the improvement of the standard of living of the population, creates conditions for the full utilization of labor resources, and the placement of small and joint ventures.

7. The development of rural settlements and the district population system will be greatly influenced by the consistent implementation of policy guidelines for the improvement of the national economy sector. Modernization of agriculture, the widespread use of new forms and methods of land use, and others contribute to the socioeconomic development of populated areas and their systems.

Expected structural changes in the spheres of agricultural production and servicing of the population will be of particular importance.
Strengthening of agriculture, organization of agro service and agribusiness stimulates the complex development of all forms of settlements-urban and rural populations of various sizes and functional profiles as elements of regional and local settlement systems.

8. The territorial organization of the population relies on both design studies and scientific management of this complex system. Therefore, it is necessary to update both new schemes for district planning of the region and districts, mineral plans for the regional planning, plan for the region and districts, mineral plans for populated areas, taking into account the social and economic policies of the sovereign state. The existing schemes and master plans are outdated and they were drawn up for "promising" areas and rural populated areas. Now there is a need to rework these project documents.

9. The management of the national economy of the country and the effectiveness of regional policy largely depend on the administrative territorial structure. In this regard, it is desirable to streamline the grid of rural areas of the region. The stability of the boundaries of the regions and the region is important with the organization of everyday life of the population, provides the opportunity to conduct large-scale historical and geographical research, reliability and reliability of statistical information.

10. This study on the problems of interconnected development of urban and rural settlements within the regional settlement system allows us to conclude that it is desirable to conduct similar work in other regions of the country. And this will be the scientific and methodological main development of the regional policy of the Republic of Uzbekistan for regulating and managing the territorial social and economic development of its constituent parts.

\section{REFERENCES}

1. Antipova E.A. Geography of world population. Belorussia, 2003. - 89 pages

2. Kayumov Kh. And others. Geography of world population. - Tashkent. 2014. - 220 pages

3. Saliev A. S. Geography of Central Asian cities population. - Tashkent. 1984. - 84 pages

4. Kadirov M.A. Geography of the population of Samarkand region (in Uzbek). Samarkand. 2017. 142 pages. 